\title{
ISLAMISASI ILMU \& RELEVANSINYA DENGAN PENDIDIKAN ISLAM; Gagasan Syed M. Naquib Al-Attas
}

\author{
Abdul Muhaimin \\ Sekolah Tinggi Ilmu Tarbiyah Raudhatul Ulum Sakatiga \\ Email: abdulmuhaimin@stit-ru.ac.id
}

\begin{abstract}
Abstrak
The problem facing Muslims today is the problem of science, that modern science is no longer valuefree (neutral), because it is influenced by religious, cultural and philosophical views. Therefore, Muslims need to Islamize contemporary science by Islamizing linguistic symbols about reality and truth. Meanwhile, in Muhaimin's view "Islamization means to Islamize or purify the science of nonMuslim (western) products. Al-Attas comprehensively conveyed the idea of the Islamization of science through several concepts. Al-Attas's conception starts from the definition of education. Education according to al-Attas is "something which is gradually implanted into humans" this is based on humans as "rational animals" (الحيوان الناطق), because of the determinant rationality of humans, that rational meaning refers to reason. Furthermore, Al-Attas said, education is "seeding and planting manners in a person - this is called ta'dib. Al-Attas then discussed the purpose of education, that the main educational goal was to prepare students to be able to achieve optimal happiness through the achievement of social and economic life success, far more successful than ever achieved by both their parents. In other words education is a tool for socio-economic mobility. The second educational goal emphasizes increasing intellectual, wealth, and mental balance of students. Al-Attas also has a metaphysical and epistemological view. Regarding the metaphysical view, AlAttas said that there are three sources and methods in Islam, namely: first, the senses of birth and mind, second reason and intuition, and third, authority. While modern western science or science limits its scope only to things that are sensory (sensible / mahsusat) or what can be known by someone, according to western scientists is everything as long as it can be observed sensually. with the liberation of human reason from doubt (syakk), prejudice (zhann), and empty argumentation (mira '), towards the attainment of belief (belief), and truth (haqq) regarding spiritual realities, reasoning, and materialities.
\end{abstract}

Keywords: Islamization, Diploma Disease, Adab-Ta'dib, Metahphysics and Epistemology

\section{Pendahuluan}

Menarik sekali apa yang menjadi keprihatinan George R. Knight bahwa mindlessnes (kesempitan berpikir) adalah kecaman yang paling pas dan relevan untuk dikenakan pada pendidikan Amerika di abad XX. Dalam konteks jagat pendidikan di Indonesia, Mahmud Arif memberikan contoh indikasi dari mindlessnes, bahwa sebagian besar masyarakat, termasuk para praktisi pendidikan, lebih bludreg dengan persoalan 'bagaimana' hidup modern daripada dengan persoalan 'mengapa' hidup modern?. Persoalan 'mengapa' adalah salah satu persoalan filosofis yang menuntuk 'kita' menyadari sepenuhnya alasan mendasari 
Islamisasi Ilmu \& Relevansinya Dengan Pendidikan Islam; Gagasan Syed M. Naquib Al-Attas.

Abdul Muhaimin

dan tujuan yang ingin dicapai dalam menggumuli kehidupan modern dan pendidikan.

Sambil menganalisis keruntuhan dan kejumudan yang terjadi di tengah-tengah umat, Iqbal mengkritik para ulama dan orang yang suka meniru-niru mereka pada zaman modern ini serta mereka yang bahwa masyarakat lebih utama daripada individu yang mampu. Dengan begitu al-Attas tidak menganggap Iqbal sebagai modernis. Modernis modern menurut al-Attas, selalu menekankan peningkatan masyarakat dan berkeyakinan bahwa masyarakat lebih penting daripada individu sehingga lebih memfokuskan perjuangannya dalam bidang politik dan hukum daripada bidang-bidang yang berupaya meningkatkan akal pikiran dan jiwa manusia.

Beberapa pandangan di atas paling tidak menggambarkan kegelisan para pemikir-pemikir besar atas kondisi dan problem seputar pendidikan. Untuk selanjutnya berusaha sersama-sama mencoba merumuskan jawaban atas pertanyaan yang mendasari hakikat problem tersebut. Pada tulisan ini, penulis memberikan deskripsi gagasan tentang islamisasi pengetahuan, dan kontribusi pemikiran tokoh Syeh Mohd Naquib al-Attas terhadap persoalan islamisasi ilmu dan pendidikan

\section{Kajian Umum Seputar Gagasan Wacana Islamisasi Ilmu}

Gagasan tentang islamisasi pengetahuan muncul pertama kali saat diselenggarakan konverensi dunia pertama tentang pendidikan muslim di Makkah pada tahun 1977 yang diprakarsai oleh King Abdul Aziz University. Konferensi dunia tersebut berhasil membahas 150 makalah yang ditulis oleh sarjana-sarjana dari 40 negara, dan merumuskan rekomendasi untuk pembenahan dan penyempurnaan sistem pendidikan Islam yang diselenggarakan oleh umat Islam di seluruh dunia. Salah satu gagasan yang direkomendasikan adalah menyangkut islamisasi pengetahuan. ${ }^{1}$

Mohd Syed Naquib Al-Attas adalah salah peserta konferensi yang mempresentasikan makalah dengan judul "preliminary on the nature of knowledge and the definition and the aims of education". ${ }^{2}$ Al-Attas mengatakan bahwa tantangan terbesar yang secara diam-diam dihadapi oleh umat Islam pada zaman ini adalah tantangan pengetahuan, bukan dalam bentuk kebodohan tetapi pengetahuan yang dipahamkan dan disebarkan ke seluruh dunia oleh peradaban barat. Gagasan ini dilontarkan Al-Attas dalam tiga temuan bahwa,

"Pertama, problem terpenting yang dihadapi umat Islam saat ini adalah masalah ilmu pengetahuan. Kedua, ilmu pengetahuan modern tidak bebas nilai (netral), sebab dipengaruhi pandangan-pandangan keagamaan, kebudayaan dan filsafat, yang mencerminkan kesadaran dan pengalaman

\footnotetext{
1 Konferensi dunia tentang pendidikan Islam kedua, diselenggarakan di Islamabad sejak tanggal 15 Maret sampai 20 Maret 1980.

${ }^{2} J u d u l$ buku tersebut dijadikan salah satu bab dari bukunya yang berjudul Islam and Securalism diterjemahkan dalam bahasa Indonesia menjadi Islam dan Sekulerisme.
} 
manusia barat. Ketiga, umat Islam, oleh karena itu, perlu mengislamkan ilmu pengetahuan masa kini dengan mengislamkan simbol-simbol linguistik mengenai realitas dan kebenaran" (Wan Daud, 2003: 315).

Al-Attas memberikan pengertian umum istilah Islamisasi, yaitu

“...pembebasan manusia dari tradisi magis, mitologis, animistis, kultur nasional (yang bertentangan dengan Islam) dan dari belenggu paham sekuler terhadap pemikiran dan bahasa. Juga pembebasan dari kontrol dorongan fisiknya yang cenderung sekuler dan tidak adil terhadap hakikat diri dan jiwanya, sebab manusia dalam wujud fisiknya cenderung lupa terhadap hakikat dirinya yang sebenarnya, menjadi bodoh akan tujuan yang sebenarnya, dan berbuat tidak adil terhadapnya. Islamisasi adalah suatu proses menuju bentuk asalnya yang tidak sekuat proses evolusi dan devolusi..." (Wan Daud, 2003: 315).

Jika dipahami dari gagasan awalnya, paradigma Islamisasi Pengetahuan lebih melihat pemikiran dan pandangan ilmuan barat sebagai ancaman yang sangat dominan dan orang Islam harus berlindung menyelamatkan identitas dan otentisitas ajaran agamanya. Menurut pandangan Muhaimin "Islamisasi berarti mengislamkan atau melakukan penyucian terhadap ilmu pengetahuan produk non-muslim (Barat)...". (Muhaimin, 2006: 40). Konsep islamisasi semacam ini dikembangkan dan dijadikan acuan dalam wacana pengembangan sistem pendidikan Islam. Jika gagasan tersebut dikontekskan dengan era globalisasi yang semakin menguat pengaruhnya terhadap berbagai dimensi kehidupan manusia termasuk dunia pendidikan Islam. Menguatkan pandangannya, Muhaimin mengutip kritik dari kedua orientalis, yaitu Ernest Renam dan William Muir, yang mengemukakan bahwa "keterbelakangan umat Islam karena peradabannya inferior (berkualitas rendah), dan ini terkait dengan agama mereka yang inferior" demikian Ma'arif menguatkan (Muhaimin, 2006: 40).

Penekanan dimensi ilmu pengetahun sebagai objek yang perlu dicarikan landasan filosofisnya yang islami, dan pandangan yang lain lebih melihat subjeknya atau pembawa dan pengembang iptek itu sendiri yang harus islami. Yang menarik untuk didiskusikan lebih lanjut adalah pandangan yaitu bagaimana mencarikan landasan filosofis sains Islam? Dan mengapa perlu adanya islamisasi?

\section{Aqidah Islam sebagai dasar ilmu pengetahuan}

Islam tidak mengharuskan setiap ilmu pengetahun bersumber dari aqidah Islam. Karena memang pada kenyataannya tidak semua ilmu pengetahuan berpangkal dari aqidah Islam. Namun demikian, setiap ilmu pengetahuan yang berkaitan dengan keimanan dan hukum harus bersumber dari aqidah Islam, karena aqidah muncul dari dua unsur, yakni keimanan dan hukum. ${ }^{3}$ Misalnya teori Darwin yang mengatakan bahwa perkembangan manusia berawal dari hewan primata.

${ }^{3}$ Lihat muqoddimah Sekilas tentang Gerakan Islamisasi Pengetahuan (Yusanto \& Widjajakusuma, 2003: xiii). 
Islamisasi Ilmu \& Relevansinya Dengan Pendidikan Islam; Gagasan Syed M. Naquib Al-Attas.

Abdul Muhaimin

Contoh lain adalah rencana kloning terhadap manusia, ide ini bila benar-benar dilakukan, jelas-jelas bertentangan dengan prinsip-prinsip Islam (Yusanto \& Widjajakusuma, 2003: xiii).

Pandangan serupa juga disampaikan Noeng Muhadjir, hukum penciptaan manusia adalah teori penciptaan atau teori organisme, sehingga tidak dapat diberlakukan riset serupa sebagaimana yang dilakukan dengan hewan. Karena menurut Noeng "manusia adalah makhluk spesial". 4 Perbedaan pandangan tersebut dapat dipahami bahwa Darwin menggunakan teori evolusi anatomi sedangkan Noeng mendukung teori evolusi organisme.

\section{Filsafat Pendidikan Syed M. Naquib Al-Attas}

\section{Konsep pendidikan dalam Islam}

Al-Attas memberikan pengertian definisi pendidikan sebagaimana dipaparkan dalam konteks Islam, dan merumuskan sistem pendidikan berdasarkan itu. Arahan kritis pada simbol-simbol linguistik yang hampir-hampir dilupakan, yaitu sifat ilmiah bahasa Arab. Pembicaraan tentang metodologi dan penerapan secara tepat simbol-simbol linguistik pertama adalah memahami sifat ilmiah bahasa Arab yang merupakan bahasa Islam, dan dasar sains Islam serta alat untuk memproyeksikan visi-visinya tentang hakikat dan kebenaran. Maka yang dimaksudkannya tentang bahasa itu adalah: karena Qur'an suci merupakan sumber ilmu yang benar. Bahasabahasa lain bisa mengalami perubahan semantik akibat perubahan sejarah dan masyarakat serta penafsiran simbol-simbol linguistik mereka. Al-Attas menguatkan argumentasinya dengan mengungkapkan kenyataan bahwa:

a. Struktuk linguistiknya dibangun atas suatu sistem "akar-akar" kata yang tegas;

b. Struktur semantiknya diatur oleh suatu sistem medan semantik (semantic field) tertentu yang menentukan struktur konseptual yang terdapat dalam kosa katanya;

c. Kata-kata, makna-makna, tata-bahasa dan persajakannya telah direkam dan dimantapkan secara ilmiah sedemikian rupa, sehingga bisa memelihara ketetapan semantiknya (Al-Attas, 1995: 16).

Sebagaimana diktum yang sudah diterima sebagian besar akademisi tentang istilah tarbiyah dimaksudkan pendidikan, tetapi berbeda dengan istilah yang dimunculkan al-Attas untuk memaksudkan pendidikan dalam pengertian Islam. Jawaban yang diberikan al-Attas meliputi tiga unsur dasar yang membentuk pendidikan yaitu: proses, kandungan, dan penerima. Unsur-unsur tersebut diberikan definisi "pendidikan adalah sesuatu yang secara bertahap ditanamkan ke dalam manusia" (Al-Attas, 1995: 35-36).

${ }^{4}$ Disampaikan dalam kuliah Filsafat Ilmu, tanggal 11 September 2008. 
Al-Attas mendefinisikan manusia sebagai "binatang rasional" di mana istilah rasional ditunjukkan oleh kata nathiq (الحيوان الناطق). Karena rasionalitas adalah penentu manusia, bahwa arti rasional mengacu pada nalar. Pendidikan, menurut alAttas adalah "penyemaian dan penanaman adab dalam diri seseorang ini disebut dengan $t a^{\prime} d i b^{\prime \prime}$ (Wan Daud, 2003: 176). Oleh karena itu, orang yang benar-benar terpelajar menurut perspektif Islam didefinisikan al-Attas sebagai orang yang beradab. Tulisnya:

Orang baik adalah orang yang menyadari sepenuhnya tanggung jawab dirinya kepada Tuhan Yang Hak; yang memahami dan menunaikan keadilan terhadap dirinya sendiri dan orang lain dalam masyarakatnya; yang terus berupaya meningkatkan setiap aspek dalam dirinya menuju kesempurnaan sebagai manusia yang beradab (Wan Daud, 2003: 176).

Konsep kunci utama ini terkandung dalam istilah (ادب). Adab adalah disiplin tubuh, jiwa dan ruh; disiplin yang menegaskan pengenalan dan pengakuan tempat yang tepat dalam hubungannya dengan kemampuan dan petensi jasmaniah, intelektual dan ruhaniah; pengenalan dan pengakuan akan kenyataan bahwa ilmu dan wujud ditata secara hirarkis sesuai dengan berbagai tingkat dan derajatnya. Karena adab menunjukkan pengenalan dan pengakuan akan kondisi kehidupan, kedudukan dan tempat yang tepat lagi layak, serta disiplin diri ketika berpartisipasi aktif dan sukarela dalam menjalankan peranan seseorang sesuai dengan pengenalan dan pengakuan itu, pemenuhannya dalam diri seseorang dan masyarakat sebagai keseluruhan mencerminkan kondisi keadilan ('adl). Keadilan itu sendiri adalah pencerminan kearifan (hikmah), yang telah didefinisikan sebagai ilmu berian Tuhan (Al-Attas, 1995: 53).

\section{Makna dan tujuan pendidikan}

Secara umum ada dua pandangan mengenai tujuan pendidikan, masingmasing dengan tingkat keberagamannya tersendiri. Pandangan yang pertama berorientasi kemasyarakatan, yaitu pandangan yang menganggap pendidikan sebagai sarana utama dalam menciptakan rakyat yang baik, baik untuk sistem pemerintahan demokratis, oligarkis, maupun monarkis. Pandangan kedua lebih berorientasi kepada individu, yang lebih memfokuskan diri pada kebutuhan, daya tampung dan minat pelajar (Wan Daud, 2003: 53). Berawal dari asumsi bahwa manusia adalah hewan yang bermasyarakat (social animal) dan ilmu pengetahuan pada dasarnya dibina di atas dasar-dasar kehidupan bermasyarakat. Mereka yang berpandangan kemasyarakatan berpendapat bahwa pendidikan bertujuan mempersiapkan manusia yang bisa berperan dan menyesuaikan diri dalam masyarakatnya masing-masing.Dengan sendirinya diambil dan diupayakan untuk

Istilah nathiq dan nuthq berasal dari sebuat akar kata yang mempunyai akar kata yang mempunyai makna dasar "pembicaraan", dalam arti pembicaraan manusia.Sehingga keduanya itu berarti suatu kekuatan dan kapasitas tertentu di dalam diri manusia untuk menyampaikan kata-kata dalam sebuah pola yang bermakna. 
Islamisasi Ilmu \& Relevansinya Dengan Pendidikan Islam; Gagasan Syed M. Naquib Al-Attas.

Abdul Muhaimin

memperkuat kepercayaan, sikap, ilmu pengetahuan dan sejumlah keahlian yang sudah diterima dan sangat berguna bagi masyarakat.

Sementara itu, pandangan teori pendidikan yang berorientasi individual terdiri dari dua aliran.Aliran pertama berpendapat bahwa tujuan utama pendidikan adalah mempersiapkan peserta didik agar bisa meraih kebahagiaan yang optimal melalui pencapaian kesuksesan kehidupan bermasyarakat dan ekonomi, jauh lebih berhasil dari yang pernah dicapai oleh orang tua mereka(Wan Daud, 2003: 53). Pendidikan adalah jenjang mobilitas social-ekonomi. Wan Mohd Nor menyebut orientasi pendidikan tersebut sebagai alat mobilitas sosial-ekonomi suatu masyarakat tertentu.

“dominasi sikap yang seperti ini dalam dunia pendidikan akan melahirkan patalogi psiko-sosial, terutama di kalangan peserta didik dan orangtua, yang terkenal dengan sebutan "penyakit diploma" (diploma disease), yaitu usaha dalam meraih suatu gelar pendidikan bukan karena kepentingan pendidikan itu sendiri, melainkan karena nilai-nilai ekonomi dan sosial". (Wan Daud, 2003: 166).

Aliran kedua lebih menekankan peningkatan intelektual, kekayaan, dan keseimbangan jiwa peserta didik. Pendidikan Islam tradisional selalu menjadikan keberhasilan individu dan kebahagiaan hidup di dunia dan akhirat sebagai cita-cita dan tujuan pendidikan yang terpenting.Namun, filsafat pendidikan yang lebih memfokuskan individu ini secara perlahan-lahan berubah ke bentuk yang lebih memfokuskan pemenuhan kebutuhan dan minat masyarakat sejat umat Islam berada di bawah pengaruh pemikiran dan institusi-institusi Barat (Wan Daud, 2003: 167).

\section{Pandangan metafisika}

Metafisika adalah cabang filsafat yang memperbincangkan tentang hakikat realitas "apakah sesuatu yang benar-benar ada itu?" merupakan pertanyaan mendasar yang diajukan dalam kajian metafisika. Metafisika pada dasarnya menggambarkan aktivitas-aktivitas perenungan dan penyintesisan dari filsafat dan memberikan kerangka kerja teoritis yang memungkinkan ilmuan menciptakan pandangan dunianya dan mengembangkan hipotesis-hipotesis yang dapat diuji sesuai dengan asumsi-asumsi dasar yang ia miliki. Lalu, teori-teori ilmu pengetahuan (sains) pada akhirnya terkait dengan teori-teori tentang realitas, dan filsafat sains mendasari eksperimen-eksperimen ilmiah, persis sebagaimana halnya filsafat pendidikan membentuk fondasi praktik pendidikan (Knight, 2007: 21-24).

Al-Attas mengakui persamaan ' $k i t a '$ dengan sains kontemporer dalam hal sumber dan metode ilmu; ketidakterpisahan cara mengetahui secara rasional dan empiris; gabungan antara realisme, idealisme, dan pragmatisme sebagai landasan kognitif suatu filsafat sains. Namun, persamaan ini dipandangnya sebagai lahiriyah belaka. Perbedaannya sebagai akibat dari perbedaan pandangan dunia dan keyakinan 'kita' mengenai hakikat akhir realitas yaitu pengakuan kita terhadap 
Volume 4 Nomor 2 Edisi Desember 2019

P-ISSN : 2541-3686

wahyu sebagai satu-satunya sumber ilmu tentang realitas dan kebenaran terakhir yang berkenaan dengan makhluk dan Khaliq-nya, memberikan landasan bagi suatu landasan metafisika.

Lebih lanjut, al-Attas menyebutkan ada tiga sumber dan metode ilmu yaitu: pertama, indera-indera lahir dan batin, kedua akal dan intuisi, dan ketiga adalah otoritas (Al-Attas, 1995: 34-39). Jika dibandingkan dengan kategorisasi yang dibuat oleh Knight (2007: 34-39) yaitu: panca indera, wahyu, otoritas, akal-pikir, intuisi. Namun, ada perbedaan yang cukup mendasar bahwa panca indera sebagai sumber pengetahuan tidak menyentuh hal di luar pengalaman empiris yang diterima melalui panca indera. Berbeda dengan Al-Attas, kelima indera batin yakni perasa tubuh, pencium, perasa lidah, penglihatan, dan pendengar semuanya berfungsi untuk mempersepsi hal-hal particular dalam dunia lahir ini, kelima hal tersebut disebutnya sebagai indera lahiriyah. Al-Attas menyebutkan bahwa ada lima indera batin yang ia sebut sebagai indera umum (common sense), representasi, estimasi, ingatan dan pengingatan kembali dan imajinasi. Dalam hal ini yang dipersepsi adalah 'rupa' (form) dari objek lahiriyah, yaitu representasi realitas lahiriyah atau inderawi, bukan realitas itu sendiri (Al-Attas, 1995: 34-35).

Selanjutnya Al-Attas menjelaskan apa yang ia maksudkan dengan kata-kata 'dalam' jiwa atau pikiran (in the soul or mind):

Ketika berbicara mengenai bentuk-bentuk intelligible yang berada 'dalam' pikiran, atau imaji-imaji yang berada 'dalam' imajinasi kognitif, kita tidak bermaksud bahwa bentuk-bentuk atau imaji-imaji itu 'termuat' di dalamnya. Namun, ia lebih merupakan konstruksi-konstruksi intelek atau pikiran ketika proses penalaran semua bentuk intelligible itu terjadi sehingga semuanya 'hadir' di dalam akal (intellect), kemudian dianggap sebagai sesuatu yang berada 'di dalam' otak; produksi imajinasi kognitif ketika pikiran memproyeksikan dunia nyata (Wan Daud, 2003: 338).

Sedangkan ilmu pengetahuan atau sains Barat modern membatasi lingkup dirinya hanya pada hal-hal yang bersifat inderawi (sensiblel mahsusat) "apa yang dapat diketahui oleh seseorang", menurut ilmuan modern adalah "segala sesuatu sejauh ia dapat diobservasi secara inderawi". Dengan kata lain, lingkup ilmu modern secara garis besar meliputi materi, makhluk hidup, pikiran, kebudayaan, alam dan sejarah. Para ilmuan muslim terutama yang klasik-berpendapat "seseorang dapat mengetahui bukan hanya benda-benda inderawi (sensibles/ mahsusat), tetapi juga substansi-substansi spiritual (intelligibles/ ma'qulat), yaitu entitas-entitas yang berada di luar dunia inderawi, yang hanya dapat diketahui melalui akal secara inferensial, atau melalui intuisi (qalb) secara langsung atau prensial. Dengan kata lain, seseorang bisa mengetahui bukan hanya alam fisik tetapi juga metafisik (Muhaimin, 2005: 47).

Dalam penjelasannya, Al-Attas menuliskan bahwa ma'qulat dipertentangkan dengan mahshushat. Proses epistemologis-psikologis sesungguhnya adalah proses 
Islamisasi Ilmu \& Relevansinya Dengan Pendidikan Islam; Gagasan Syed M. Naquib Al-Attas.

Abdul Muhaimin

abstraksi dari realitas lahir menjadi hal-hal yang terindera (mahshushat/ sensible), lalu diabstraksi lebih jauh menjadi cita-cita akliah ( $m a^{\prime}$ qulat/ intelligibles). Indera-indera batin berurusan dengan mahshushat, sementara diri rasional berurusan dengan ma'qulat. Proses abstraksi menjadi citra akliah ini disempurnakan oleh akal (AlAttas, 1996: 34).

\section{Pandangan epistemologi}

Epistemologi atau teori pengetahuan, adalah titik pusat setiap pandangan dunia.Epistemologi berusaha mendifinisikan pengetahuan, membedakan variasivariasi utamanya, menandai sumber-sumbernya dan menentukan batasbatasnya.Apa yang dapat diketahui, dan bagaimana mengetahuinya? Adalah pertanyaan-pertanyaan pokok epistemologi.Tanggapan terhadap pertanyaanpertanyaan ini mengandung implikasi-implikasi bagi setiap aspek aktivitas manusia.Jenis masyarakat yang dibangun merupakan hasil langsung dari tanggapan ini.

Tema yang ditulis Sardar mengisyaratkan ada sesuatu yang hilang dari umat Islam, bahwa epistemologi Islam tentang konsep 'ilm yang mewakili konsep peradaban Muslim tidak lagi murni dan merdeka. Kondisi seperti ini dinamakan Sardar sebagai penjajahan epistemologi

"penjajahanepistemologi ini telah menancapkan akar-akarnya sejak lebih dari 300 tahun lalu. Asalnya adalah pada permulaan petualangan colonial Eropa dan munculnya rasionalitas ilmiah sebagai satu-satunya metoda yang sah untuk memahami dan mengontrol alam. Epistemologi sains modern itulah yang menciptakan cara di mana individu-individu dalam masyarakat-masyarakat industry memikirkan tentang dunia mereka, berusaha untuk mengetahui, memahami, dan mengontrolnya".

Dikotomi antara fakta dan nilai, realitas objektif dan emosi subjektif merupakan ciri utama epistemologi sains modern.

Al-Attas mengungkapkan pandangan ini dengan jitu: "ilmu (Barat) telah menimbulkan masalah, sebab ia telah kehilangan tujuan hakikinya karena tidak dicerna dengan semestinya. Akibatnya ia membawa kekacauan dalam kehidupan manusia dan bukannya kedamaian dan keadilan. Ilmu tersebut nampaknya benar tetapi sesungguhnya lebih produktif ke arah kekeliruandan skeptisme, ilmu yang buat pertama kali dalam sejarah membawa kekacauanbalauan isi alam semesta: hewan, tumbuhan dan logam. Pemahaman ilmu dan tashowwur barat ini menular ke negara-negara muslim setelah berlangsungnya penjajahan di mana banyak negara muslim dijajah oleh negara-negara barat seperti Inggris dan Perancis. Sistem pendidikan yang mereka dirikan juga didukung oleh pandangan hidup barat. Ini mengakibatkan kekeliruan, dan manusia muslim kehilangan adab. 
RAUDHAH Proud To Be Professionals Jurnal Tarbiyah)damiyah

Volume 4 Nomor 2 Edisi Desember 2019

P-ISSN : 2541-3686

Secara epistemologis, islamisasi berkaitan dengan pembebasan akal manusia dari keraguan (syakk), prasangka (zhann), dan argumentasi kosong (mira'), menuju pencapaian keyakinan (yakin), dan kebenaran (haqq) mengenai realitas-realitas spiritual, penalaran, dan material (Wan Daud, 2003: 336).

Secara ringkas gagasan islamisasi Al-Attas dapat dilihat dalam skema di bawah ini:

Memahami worldview Islam

Memahami konsep dasar Islam:

- Din - Ilmu ('ilm dan ma'rifat)

- Keadilan - Manusia (insan)

- Amal yang benar (amal sebagai adab)

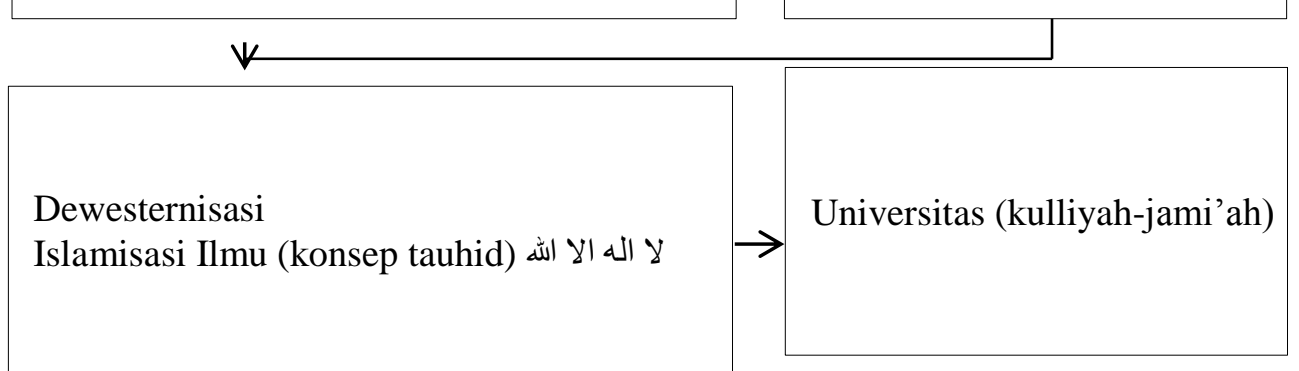


Islamisasi Ilmu \& Relevansinya Dengan Pendidikan Islam; Gagasan Syed M. Naquib Al-Attas.

Abdul Muhaimin

\section{DAFTAR PUSTAKA}

Al-Attas, Syed M. Naquib, Islam and Philosophy of Science, Saiful Muzani (penj), Islam dan Filsafat Sains, Bangung: Mizan, 1995.

Al-Attas, Syed M. Naquib, The Concept of Education in Islam: A Framework for an Islamic Philosophy of Education. Haidar Bagis (penj), Konsep Pendidikan dalam Islam, Bandung: Mizan, 1996.

Muhamin, Nuansa Baru Pendidikan Islam: Mengurai Benang Kusut Dunia Pendidikan, Jakarta: Raja Grafindo Persadam 2005.

R. Knight, George, Issues and Alternatives in Educational Philosophy, Arif, Mahmud (penj), Filsafat Pendidikan, Yogyakarta: Gama Media, 2007.

Sardar, Ziauddin, Islamic Futures: The Shape of Ideas to Come, Astuti, Rahmani (penj), Masa Depan Islam, Bandung: Pustaka, 1985.

Wan Daud, Wan Mohd Nor, Filsafat dan Praktik Pendidikan Islam Syed M. Naquib Al-Attas, Bandung: Mizan, 2003.

Yusanto, Ismail, Muhammad dan Widjajakusuma, Karebet, Muhammad, Sekilas tentang Gerakan Islamisasi Pengetahuan dalam buku Manajemen Strategis Perspektif Syariah, Jakarta: Khairul Bayaan, 2003.

Zarkasyi, Hamid Fahmy, malakah Worldview Islam: Asas Ilmu Pengetahuan Kontemporer. Disampaikan dalam serial kuliah Islam komtemporer (SKIK) HIMPAS UGM, 28 April 2008. 